\title{
Relationship between sexual signals and louse (Insecta: Phthiraptera) infestation of breeding and migrating Barn swallows (Hirundo rustica) in Hungary
}

\author{
ENIKÖ GÁL ${ }^{1}$, Tibor CsÖrgö2 ${ }^{2}$ ZOLTÁN VAS 3 3,4,5,*
}

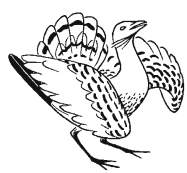

Enikő Gál, Tibor Csörgő \& Zoltán Vas 2012. Relationship between sexual signals and louse (Insecta: Phthiraptera) infestation of breeding and migrating Barn swallows (Hirundo rustica) in Hungary. - Ornis Hungarica 20(1): 37-43. lows (Hirundo rustica). The number of these holes correlate positively with the intensity of louse infestation, hence hole counts are useful to quantify lousiness. Several papers showed that lice affect both life expectancy and reproductive success of hosts. In male Barn swallows, the length of the outermost tail feathers act as a sexual signal. Females prefer long-tailed males, which have significantly fewer feather holes. In this study we sampled breeding and migrating Barn swallows and compared their louse burden, and the relationship between tail length and the number of feather holes. We found significant negative correlation between feather holes and tail length in breeding males; however, we found non-significant correlation in migrating males. We suggest that attractive males have more physical interactions (e.g. extra-pair copulation) during the breeding season, than less attractive males, hence they are more exposed to louse transmission, and therefore the difference in the infestation declines towards the end of the breeding season. However, given that migrating swallow groups include colonial and solitary breeding birds, it cannot be excluded that a potentially different louse distribution on solitary breeding birds may contribute to the results.

Keywords: ectoparasites, lice, feather holes, extra-pair copulation, sexual selection

Összefoglalás A füsti fecskék (Hirundo rustica) evezö- és faroktollain a tolltetvek (Phthiraptera) karakterisztikus lyukakat rágnak. A toll-lyukak száma korrelál a tolltetü fertőzöttség intenzitásával, így a toll-lyukak megszámolásával a fertőzöttség jól becsülhető. A magasabb tolltetü fertőzöttségi intenzitás a füsti fecskék túlélési és szaporodási esélyeit is csökkenti. A hosszabb szélső faroktollú füsti fecske hímek kevésbé fertőzöttek, mint a rövidebb farkúak, így a szélső faroktollak hossza a fertőzöttség megbízható jelzéseként szolgálhat a tojók számára. Munkánkban vizsgáltuk, hogy a költési időszak során, a vonulási időszakra megváltozik-e a költő populációkban kimutatott negatív korreláció a szexuális szignálok és a tolltetü-fertőzöttség között. Költési időszakban és vonulási időszakban jelölt füsti fecskéken összehasonlítottuk a toll-lyukak gazdaegyedek közötti eloszlását, a fertőzöttség mérőszámait és öszszefüggését a szexuális szignálok kifejezettségével. A költő hímeknél negatív korrelációt találtunk a farokhossz és a toll-lyukak száma közt, a vonuló hímeknél azonban ez az összefüggés nem volt kimutatható. Hipotézisünk szerint a költési időszak során a „,vonzóbb” hímek gyakrabban és több fajtárssal kerülnek fizikai kontaktusba, mint „,kevésbé vonzó" társaik, így ezek során nagyobb esélyük van tolltetvekkel fertőződni, ezáltal a költési időszak elején lévő fertőzöttségbeli különbség a vonulási időszakra lecsökkenhet. Ugyanakkor a minták különböző összetétele (a vonuló csapatokhoz magányosan költö madarak is társulnak) is hozzájárulhat a kapott eredményhez.

Kulcsszavak: élősködés, ektoparazita, toll-lyuk, ivari szelekció

${ }^{1}$ H-1164 Budapest, Bóbitás str. 24., Hungary, ${ }^{2}$ Eötvös Loránd University, Institute of Biology, Department of Anatomy, Cell and Developmental Biology, H-1117 Budapest, Pázmány str. 1/C, Hungary, ${ }^{3}$ Szent István University, Faculty of Veterinary Science, Department of Biomathematics and Informatics, H-1078 Budapest, István str. 2., Hungary, ${ }^{4} H u n-$ garian Natural History Museum, Department of Zoology, H-1088 Budapest, Baross str. 13., Hungary, e-mail: vas. zoltan@gmail.com, ${ }^{5}$ Ócsa Bird Ringing Station, H-2364 Ócsa, Némedi str. 592/1., Hungary, "corresponding author 


\section{Introduction}

Lice (Insecta: Phthiraptera) are wingless, quite host-specific obligate ectoparasites of birds and mammals. They complete their entire life-cycle on the body surface of their hosts; hence their transmission requires direct physical contact among host individuals. Price et al. (2003) summarized their taxonomy, distribution and biology (for a Hungarian overview see Rózsa 2003).

Feather lice chew characteristic holes on the remiges and rectrices of Barn swallows (Hirundo rustica) as first described by Møller (1991) based on a strong positive correlation between the number of feather holes and the intensity of louse infestation. Møller (1991) suggested that the causative agent of feather holes is either Machaerilaemus malleus or Myrsidea rustica (Phthiraptera: Amblycera), however, a more recent study found that feather holes are more likely the chewing traces of Brueelia domestica (Phthiraptera: Ischnocera). Given that the diametrical size of these holes is about $0.5-1 \mathrm{~mm}$, their count is highly repeatable, hence hole counts act as a proxy of the intensity of louse infestation (Møller 1991). In the recent years several important studies in parasite ecology were based on the feather holes of Barn swallows (Møller 1991, Saino et al. 1997, Kose et al. 1999, Kose \& Møller 1999, Garamszegi et al. 2005, Pap et al. 2005).

The intensity of louse infestation affects both life expectancy and reproductive success in Barn swallows. Lice damage the structure of important flight feathers (and even cause feather breakage in extreme cases) by chewing feather holes. Hence, hosts with high louse intensity may have an aerodynamical disadvantage, causing higher mortality during migration (Kose \& Møller 1999, Barbosa et al. 2003, Pap et al. 2005).
Additionally, sexual selection may disfavour males with high louse burden, too. According to the theory of parasite-mediated sexual selection, females tend to choose uninfested males to ensure the parasiteresistant alleles for their offsprings and to avoid parasite transmission from the mates (Hamilton \& Zuk 1982, Clayton 1991, Able 1996). In Barn swallow males, the length of the outermost tail feathers (and the size of white patches on the tail feathers) act as sexual signals for females, and - as expected - there is a significant negative correlation between the expression of sexual signals and the intensity of louse infestation (Møller 1991).

Several latter studies on Barn swallows confirmed the negative correlation between sexual signals and louse intensity, and provided further details such as males with longer tails arrive in better condition from spring migration, start the breeding earlier and have a greater chance for a second clutch during the breeding season than males with shorter tail feathers (Kose et al. 1999, Kose \& Møller 1999, Garamszegi et al. 2005, Pap et al. 2005). Saino et al. (1997) showed that males with longer tails are more resistant against blood parasites, than males with shorter tails. Males with more expressed sexual signals may also be more frequently involved in extra-pair copulations (EPC), as there are significantly more nestlings from foreign males (i.e. EPC-nestlings) in the clutches of short-tailed males, than in the clutches of long-tailed ones (Møller et al. 2003).

However, all of the studies mentioned above were based on observations and experiments conducted in the breeding season. There is much less known about the relationship between sexual signals and louse infestation after breeding, during the dispersion and migration period. Nevertheless, 
there are hints that this co-variation may change over the breeding season. Barbosa et al. (2003) shoved that Barn swallow males with longer tail feathers suffer from more feather breakage until migration period, than males with shorter tails. Another hint that Burley et al. (1991) found a positive correlation between the expression male sexual signals and louse infestation after the breeding season in Zebra finches (Taeniopygia guttata).

In this study we examine the relationship between the expression of sexual signals (tail length) and the number of feather holes as proxy of the intensity of louse infestation, and compared it between breeding and migrating male Barn swallows to test whether there are any changes in this relationship over the breeding season and dispersion period. Our hypothesis was that the negative correlation found in the breeding season may disappear until migration, and even the direction of the relationship may turn to a positive correlation; due to males with more expressed sexual signals have more direct physical contact with other birds (e.g. EPC, fight), hence they are more exposed to horizontal louse transmission than less attractive males.

\section{Materials and methods}

Barn swallows are excellent candidates for ectoparasitological studies; due to semi-colonial breeding, complex social life and frequent body-to-body contacts the prevalence of their ectoparasites are usually high. Birds were ringed and sampled at Világospuszta Cattle Farm (Fejér County, Hungary) in the breeding season (May-July, 2006-2010) and at Ócsa Bird Ringing Station (Pest County, Hungary) in the migration period
(15. August -13 . September, 2003). Swallows caught at Világospuszta were not separated by years in the analyses, rather were pooled together by representing each bird with its first caught.

Birds were caught with mist nets and marked individually with aluminium rings. We determined their sex and age according to Svensson (1995), and recorded their standard biometrical measures $\left(3^{\text {rd }}\right.$ primary length, wing length and tail length, all measured on the left side of the bird) and condition scores (Svensson 1995). Feather holes were counted on each remiges and rectrices, and summed thereafter in subsequent analyses. Adult females and young (i.e. first calendar year old) birds were omitted from the analyses.

Statistical analyses were carried out with Quantitative Parasitology 3.0 (Reiczigel \& Rózsa 2005) and with R Commander (Fox et al. 2009) package in R 2.10.1 (R Development Core Team 2009). Prevalences were compared with Fisher's exact test, mean intensities with bootstrap- $t$ test, and median intensities with Mood's median test (Rózsa et al. 2000, Rózsa 2003, 2005). We used Kendall's tau correlation as this nonparametric method is less sensible to the effect of outlier data points commonly present in aggregated distributions than Spearman's rank correlation (Reiczigel et al. 2007). All reported $P$-values are two-tailed.

\section{Results}

The distribution of the feather hole intensities among host individuals was aggregated in both samples (variance / mean abundance ratio $>1$; Table 1), as it was expected from parasite distributions (Crofton 1971). We compared the prevalences, mean and me- 


\begin{tabular}{|c|c|c|}
\hline & breeding season & migration period \\
\hline prevalence & 0.97 & 0.98 \\
\hline $\mathbf{9 5} \%$ confidence interval & $0.91-0.99$ & $0.91-1.00$ \\
\hline mean intensity & 26.5 & 24.0 \\
\hline $\mathbf{9 5} \%$ confidence interval & $22.9-30.2$ & $19.6-28.8$ \\
\hline median intensity & 23.0 & 19.0 \\
\hline $\mathbf{9 5} \%$ confidence interval & $18-27$ & $13-27$ \\
\hline variance / mean abundance ratio & 13.6 & 14.1 \\
\hline
\end{tabular}

Table 1. Descriptive statistics of feather holes on Barn swallows in the samples from the breeding season (Világospuszta) and from the migration period (Ócsa)

1. táblázat A toll-lyukak statisztikái a fészkelési (Világospuszta) és vonulási időszakban (Ócsa)

dian intensities of feather holes between Barn swallow males caught in the breeding season $(\mathrm{n}=97)$ at Világospuszta, and in the migration period $(n=60)$ at Ócsa; however, none of these measures differed significantly $(\mathrm{P}=0.99,0.39,0.32$, respectively) between the two samples.
We found a significant negative correlation between the number of feather holes and tail length in breeding males (tau $=-0.16, \mathrm{P}$ $=0.04$; Fig. 1); however we found no significant correlation in the case of migrating males (tau $=-0.15, \mathrm{P}=0.11$; Fig. 2).

Figure 1. Relationship between tail length and the number of feather holes in breeding males 1. ábra A hímek farokhossza és a toll-lyukak száma közötti összefüggés a költési időszakban

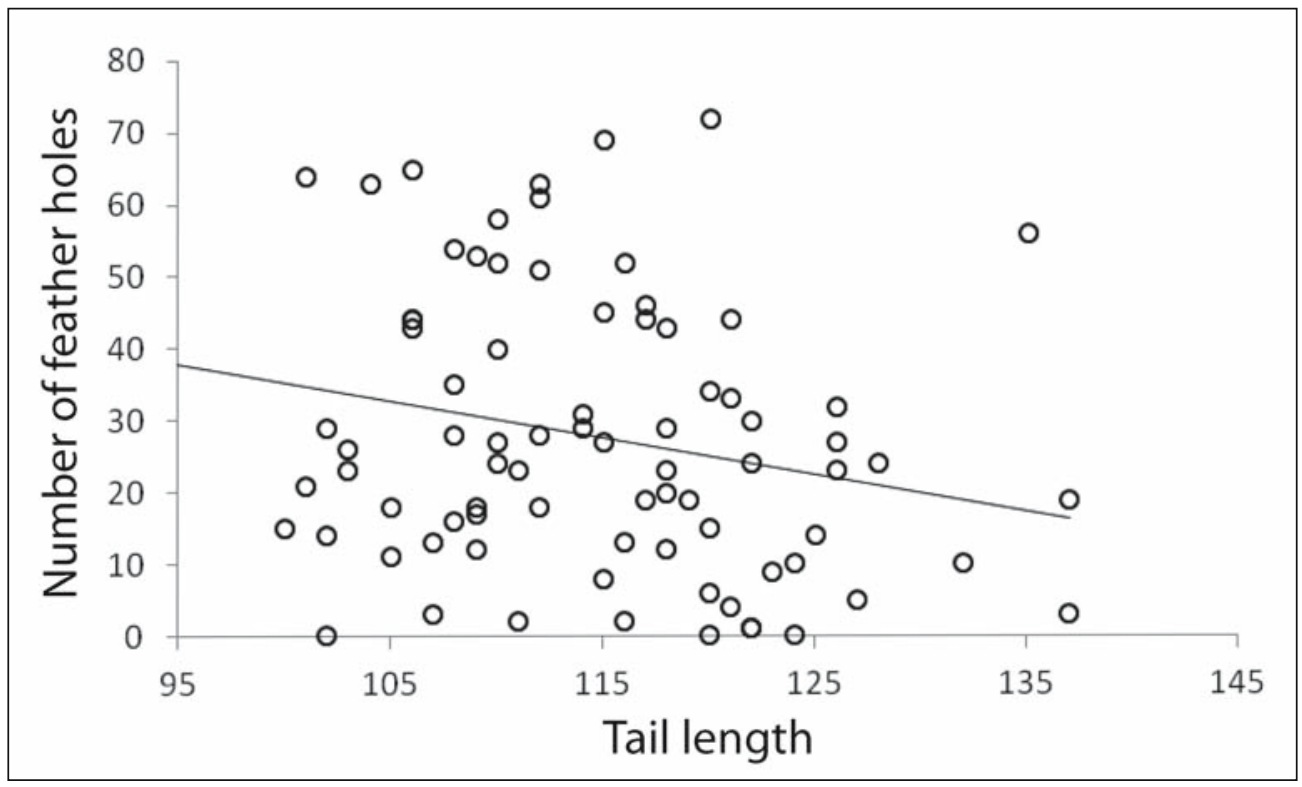




\section{Discussion}

We found no significant differences in prevalence, mean and median intensity between the breeding and migrating males (see above). Prevalence was quite high in both samples (Table 1), probably due to the semi-colonial breeding of the host. Rózsa et al. (1996) showed that colonial birds are characterised by higher ectoparasite prevalence and less aggregated parasite distribution among host individuals than territorial birds.

In the case of breeding males, we found a significant negative correlation between tail length and the number of feather holes (Fig. 1), confirming the results of previous studies carried out in the breeding season (see e.g. Møller 1991, Kose et al. 1999, Kose \& Møller 1999, Pap et al. 2005). These results suggest that the length of the outermost tail feather indeed act as an honest sexual signal of parasite load in the breeding season.
However, according to our hypothesis, this relationship seems to change during the late breeding season and dispersion period, as the same correlation was not significant in the sample of migrating males (Fig. 2). This result is in concordance with the findings of Burley et al. (1991) and Barbosa et al. (2003); however, we could not prove a turn in the direction of the relationship.

There are at least two, mutually not exclusive hypotheses to explain the disappearance of the significant negative relationship between the expression of sexual signals (tail length) and intensity of louse infestation (feather holes).

We suggested that more attractive males (i.e. with more expressed sexual signals) are more exposed to louse transmission due to more frequent body-to-body contacts with conspecifics, such as more frequent EPC (Møller et al. 2003) or fights with other males. Recent studies showed that the number

Figure 2. Relationship between tail length and the number of feather holes in migrating males

2. ábra A hímek farokhossza és a toll-lyukak száma közötti összefüggés a diszperziós és vonulási időszakban

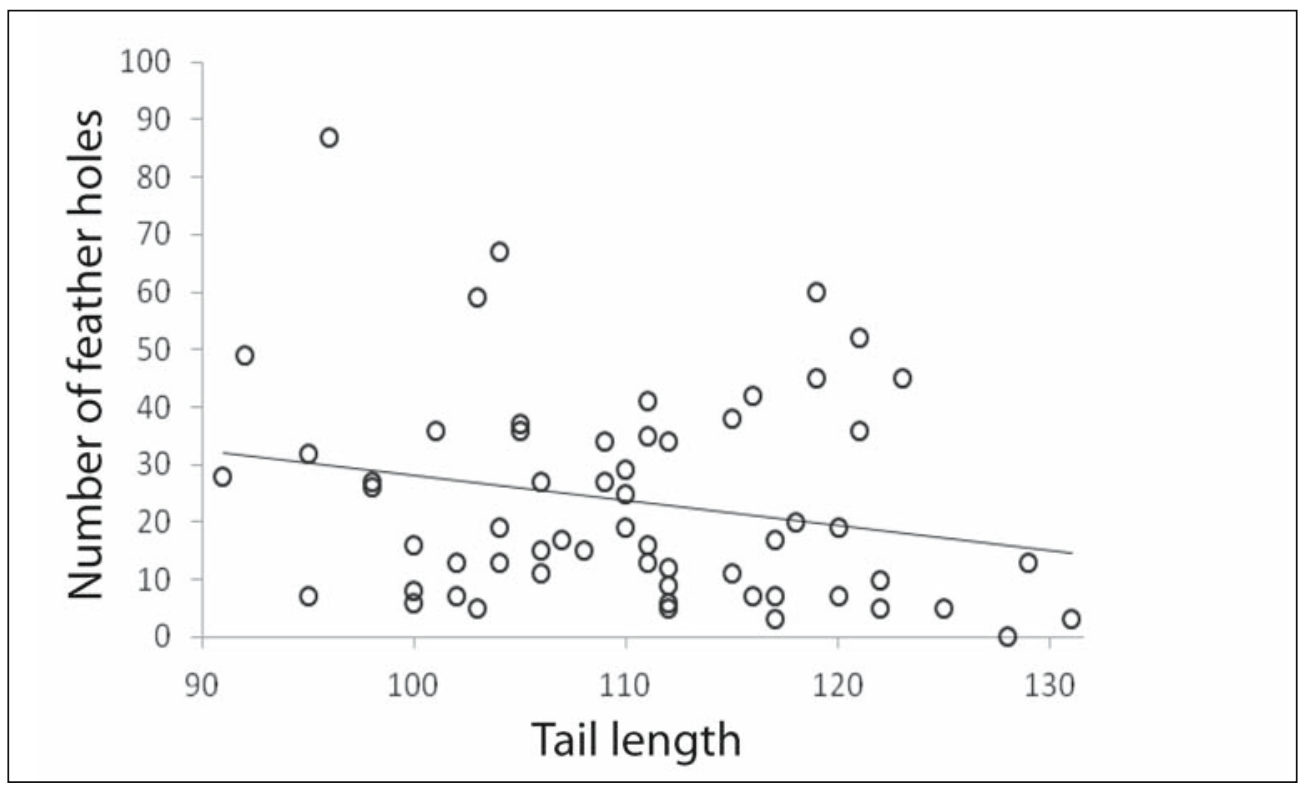


of feather holes increased significantly during the breeding season in adult Barn swallows (Vas et al. 2008, Vas \& Fuisz 2010). Hence we suggest this increase is higher in attractive males during the breeding season than in less attractive ones. At beginning of the breeding season, attractive males harbour fewer lice; however, due to frequent horizontal louse transmission, the difference in louse infestation sinks toward migration period.

The benefit of attractiveness in the sexual selection may result a handicap in natural selection. Barbosa et al. (2003) found a significant positive correlation between Barn swallows' tail length and the amount of damaged tail feathers in the end of the breeding season. The authors of this study did not consider louse infestation; however, Kose and Møller (1999) previously showed that lice can cause feather breakage by chewing holes. Given that Barn swallows are long-term migrants (Szép 2009), the aerodynamical disadvantage caused by damaged or broken tail feathers may results higher mortality during migration (Pap et al. 2005).

Nevertheless, we cannot exclude an alternative hypothesis, based on the fact that the sampled populations differed both spatially and temporally. However, sampling the same birds in breeding season and in the migration period has serious methodological limits. Once the nestlings fledged, Barn swallows spread in the ca. $5 \mathrm{~km}$ area of the nesting site and do not return to the nest even for nights (Szép 2009), hence their recapture is almost impossible. Additionally, according to (Szép 2009), migrating groups gather from quite huge area, and consist of both colonially and solitarily breeding birds. Hence, the difference we found may be explained by the different compound of the samples. The breeding sample contained only colonial swallows, while it is very likely that some solitary birds were represented in the migrating sample. Until now, no study examined the louse infestation of solitarily breeding Barn swallows. Given the fact that that in the case of solitary males the body-to-body contact with conspecific birds is very limited, arguably their louse load may differ from colonial ones. We cannot exclude that this phenomenon may contribute to our results. Future studies should consider the solitarily breeding Barn swallow pairs as well to understand the complex system built by this species and their ectoparasitic lice.

\section{Acknowledgements}

We are grateful to the volunteers of Ócsa Bird Ringing Station for their valuable help in field work. We thank Á. Varga, the director and the staff (especially L. Mulady) of the Világospuszta Cattle Farm (Mezőfalvai Mg. Zrt. Világospusztai Tehenészeti Telep) for allowing us to work on their premises. We are especially grateful to L. Rózsa, J. Rékási, D. Winkler and Gy. Traser for their valuable comments on a former version (the first author's MSc thesis) of this manuscript. 


\section{References}

Able, J. D. 1996. The contagion indicator hypothesis for parasite-mediated sexual selection. - Proceedings of the National Academy of Science, USA 93: 2229-2233.

Barbosa, A., Merino, S., Cuervo, J. J., de Lope, F. \& Møller, A. P. 2003. Feather damage of long tails in Barn swallow Hirundo rustica. - Ardea 91: 85-90.

Burley, N., Tidemann, S. C. \& Halupka, K. 1991. Bill colour and parasite levels of Zebra finches. - in: Loye, J. E. \& Zuk, M. (eds.) Bird-parasite interactions. - Oxford University Press, Oxford pp. 359-376.

Clayton, D. H. 1991. The influence of parasites on host sexual selection. - Parasitology Today 12: 329-334.

Crofton, H. D. 1971. A quantitative approach to parasitism. - Parasitology 62: 179-193.

Fox, J., Andronic, L., Ash, M., Boye, T., Calza, S., Shang, A., Grosjean, P., Heiberger, R., Kerns, G. J., Lancelot, R., Lesnodd, M., Ligges, U., Messad, S., Maechler, M., Muenchen, R., Murdoch, D., Neuwirth, E., Putler, D., Ripley, B., Ristic, M. \& Wolf, P. 2009. Rcmdr: R Commander. R package version 1.5-4. Available at http://CRAN.R-project. org/package $=$ Rcmdr.

Garamszegi, L. Zs., Heylen, D., Møller, A. P., Eens, M. $\&$ de Lope, F. 2005. Age-dependent health status and song characteristics in the Barn swallow. - Behaviour Ecology 16: 580-591.

Hamilton, W. D. \& Zuk, M. 1982. Heritable true fitness and bright birds: a role of parasites? - Science 218: 384-387.

Kose, M., Mänd, R. \& Møller, A. P. 1999. Sexual selection for white tail spots in the Barn swallow in relation to habitat choice by feather lice. - Animal Behaviour 58: 1201-1205.

Kose, M. \& Møller, A. P. 1999. Sexual selection, feather breakage and parasites: the importance of white spots in the tail of the Barn swallow (Hirundo rustica). - Behaviour Ecology and Sociobiology 45: 430-436.

Møller, A. P. 1991. Parasites, sexual ornaments and mate choice in the Barn swallow Hirundo rustica. - in: Loye, J. E. \& Zuk, M. (eds.) Bird-parasite interactions: Ecology, evolution and behaviour. - Oxford University Press, Oxford pp. 328-343.

Møller, A. P., Brohede, J., Cuervo, J. J., de Lope, F. \& Primmer, C. 2003. Extrapair paternity in relation to sexual ornamentation, arrival date, and condition in a migratory bird. - Behaviour Ecology 14: 707-102.

Pap, P. L., Tökölyi, J. \& Szép, T. 2005. Frequency and consequences of feather holes in Barn swallows Hirundo rustica. - Ibis 147: 169-175.
Price, R. D., Hellenthal, R. A., Palma, R. L., Johnson, K. P. \& Clayton, D. H. (eds.) 2003. The chewing lice, world checklist and biological overview. - Illinois Natural History Survey, Champaign, IL

R Development Core Team 2009. R: A language and environmental for statistical computing. R Foundation for Statistical Computing, Vienna, Austria, ISBN 3-900051-07-0 URL. Available at http://www.Rproject.org.

Reiczigel, J., Harnos, A. \& Solymosi, N. 2007. Biostatisztika nem statisztikusoknak [Biostatistics for nonstatisticians]. - Pars Kft., Nagykovácsi

Reiczigel, J. \& Rózsa, L. 2005. Quantitative Parasitology 3.0. - Budapest

Rózsa, L. 2003. A madarak tetvei (Phthiraptera) [Avian lice (Phthiraptera)]. - Állattani Közlemények 88: 2-29.

Rózsa, L. 2005. Élősködés: az állati és emberi fejlődés motorja [Parasitism: a driving force of animal and human evolution]. - Medicina Könyvkiadó Rt., Budapest

Rózsa, L., Reiczigel, J. \& Majoros, G. 2000. Quantifying parasites in samples of hosts. - Journal of Parasitology 86: 228-232.

Rózsa, L., Rékási, J. \& Reiczigel, J. 1996. Relationship of host coloniality to the population ecology of avian lice (Insecta: Phthiraptera). - Journal of Animal Ecology 65: 242-248.

Saino, N., Bolzern, A. M. \& Møller, A. P. 1997. Immunocompetence, ornamentation, and viability of male Barn swallows (Hirundo rustica). - Proceedings of the National Academy of Science, USA 94: 549-552.

Svensson, L. 1995. Útmutató az európai énekesmadarak határozásához [Identification guide to the European passerines]. - Magyar Madártani és Természetvédelmi Egyesület, Budapest

Szép, T. 2009. Füsti fecske [Barn swallow]. - in: Csörgö, T., Karcza, Zs., Halmos, G., Magyar, G., Gyurácz, J., Szép, T., Bankovics, A., Schmidt, A. \& Schmidt, E. (eds.) Magyar Madárvonulási Atlasz [Hungarian Bird Ringing Atlas]. - Kossuth Kiadó Zrt., Budapest pp. 409-414.

Vas, Z., Csörgő, T., Møller, A. P. \& Rózsa, L. 2008. The feather holes on the Barn swallow Hirundo rustica and other small passerines are probably caused by Brueelia spp. lice. - Journal of Parasitology 94: 1438-1440.

Vas, Z. \& Fuisz, T. I. 2010. Ringing procedure can reduce the burden of feather lice in Barn swallows Hirundo rustica. - Acta Ornithologica 45: 203-207. 